\title{
Prediction of Life-threatening and Disabling Bleeding in Patients with Acute Myeloid Leukemia Receiving Intensive Induction Chemotherapy
}

Jurjen Versluis, ${ }^{1}$ Manu Pandey, ${ }^{2}$ Yael Flamand, ${ }^{3}$ J. Erika Haydu, ${ }^{1}$ Roger Belizaire, ${ }^{4}$ Rahul S. Vedula, ${ }^{1}$ Anne Charles, ${ }^{1}$ Kevin M. Copson, ${ }^{1}$ Shai Shimony, ${ }^{5}$ Alon Rozental, ${ }^{5}$ Pavan K. Bendapudi, ${ }^{6}$ Ofir Wolach, ${ }^{5}$ Elizabeth A. Griffiths, ${ }^{2}$ James E. Thompson, ${ }^{2}$ Richard M. Stone, ${ }^{1}$ Daniel J. DeAngelo, ${ }^{1}$ Donna Neuberg, ${ }^{3}$ Marlise R. Luskin, ${ }^{1}$ Eunice S. Wang, ${ }^{2}$ and R. Coleman Lindsley ${ }^{1}$

1 Department of Medical Oncology, Dana-Farber Cancer Institute, Harvard Medical School, Boston, MA, USA;

2 Department of Medicine, Roswell Park Comprehensive Cancer Center, Buffalo, NY, USA;

3 Department of Data Science, Dana-Farber Cancer Institute, Boston MA, USA;

4 Department of Pathology, Division of Transfusion Medicine, Brigham and Women's Hospital and Harvard Medical School, Boston, MA, USA;

5 Institute of Hematology, Davidoff Cancer Centre, Beilinson Hospital, Rabin Medical Center, Petah-Tikva, Israel and Sackler medical school, Tel Aviv University, Tel Aviv, Israel.

6 Division of Hematology and Blood Transfusion Service, Massachusetts General Hospital, Boston, MA, USA;

Running title: prediction of grade 4 bleeding in AML patients

\section{Corresponding Author:}

R. Coleman Lindsley, MD, PhD

Dana-Farber Cancer Institute

450 Brookline Avenue

Boston, MA 02215

E-mail: coleman_lindsley@dfci.harvard.edu

Presented in abstract form at the 62nd Annual Meeting of the American Society of Hematology, 5-8 December 2020.

\section{Counts}

Abstract

Text

Tables/Figures

References
232 words

3162 words

$4 / 2$ 
medRxiv preprint doi: https://doi.org/10.1101/2021.09.24.21263986; this version posted September 27, 2021. The copyright holder for this preprint (which was not certified by peer review) is the author/funder, who has granted medRxiv a license to display the preprint in perpetuity.

It is made available under a CC-BY-NC-ND 4.0 International license .

\section{ABSTRACT}

Bleeding in patients with acute myeloid leukemia (AML) receiving intensive induction chemotherapy is multifactorial and contributes to early death. We sought to define incidence and risk factors of grade 4 bleeding to support strategies for risk mitigation. Bleeding events were assessed according to the WHO bleeding assessment scale, which includes grade 4 bleeding as fatal, life-threatening, retinal with visual impairment, or involving the central nervous system. Using multivariable competing-risk regression analysis with grade 4 bleeding as the primary outcome, we identified risk factors in the development cohort $(n=341)$, which were tested in an independent cohort $(n=143)$. Grade 4 bleeding occurred in $5.9 \%$ and $9.8 \%$ of patients in the development and validation cohort, respectively. Risk factors that were independently associated with grade 4 bleeding included baseline platelet count $\leq 40 \times 10^{9} / \mathrm{L}$ compared with $>40 \times 10^{9} / \mathrm{L}$, and baseline PT-INR $>1.5$ or $>1.3-1.5$ compared with $\leq 1.3$. These variables were allocated points, which allowed for stratification of patients with low- and high-risk for grade 4 bleeding. Cumulative incidence of grade 4 bleeding at day+60 was significantly higher among patients with high- versus low-risk (development: $31 \pm 7 \%$ vs. $2 \pm 1 \%, P<0.001$, validation: $25 \pm 9 \%$ vs. $7 \pm 2 \%, P=0.008)$. In both cohorts, high bleeding risk was associated with disseminated intravascular coagulation (DIC) and proliferative disease. We developed and validated a simple risk model for grade 4 bleeding, which enables development of rational risk mitigation strategies to improve early mortality of intensive induction treatment. 
medRxiv preprint doi: https://doi.org/10.1101/2021.09.24.21263986; this version posted September 27, 2021. The copyright holder for this preprint (which was not certified by peer review) is the author/funder, who has granted medRxiv a license to display the preprint in perpetuity. It is made available under a CC-BY-NC-ND 4.0 International license .

\section{KEY POINTS}

- Risk factors predicting grade 4 bleeding were consistent with DIC-like coagulopathy, including prolonged PT-INR and thrombocytopenia.

- The grade 4 bleeding score was externally validated and allows for preventive strategies to improve early mortality in high-risk patients. 


\section{INTRODUCTION}

Bleeding is a major cause of early morbidity and mortality in patients with acute myeloid leukemia (AML) who are treated with intensive chemotherapy. ${ }^{1,2}$ Despite monitored, hospital-based treatment and standardized thresholds for prophylactic transfusions, cooperative group trials have reported Common Terminology Criteria for Adverse Events (CTCAE) grade 3 to 5 bleeding in $2 \%$ to $8 \%$ of AML patients. ${ }^{3-6}$ Prospective identification of patients at increased risk for high-grade bleeding could improve overall treatment outcomes through development of focused preventive strategies.

Widely used predictive models have enabled improved definition of overall induction fitness, but do not predict cause-specific outcomes or justify specific strategies for risk mitigation. ${ }^{7-9}$ Bleeding represents a particular challenge due to the multifactorial and dynamic nature of risk. Various factors have been associated with risk of high-grade bleeding specifically in leukemia patients, including severe thrombocytopenia, reduced platelet function test, abnormal coagulation parameters, hyperleukocytosis, older age, and female sex, but these were identified in mixed disease cohorts including patients with acute promyelocytic leukemia (APL) and other myeloid malignancies, or focused on bleeding in specific sites, such as the central nervous system (CNS). ${ }^{10-13}$ Risk factors for overall life-threatening and disabling bleeding events in newly diagnosed, non-APL AML patients receiving initial treatment with intensive chemotherapy have not been specifically studied. 
We therefore used a consecutive cohort of adults with (non-APL) AML treated with intensive anthracycline-based chemotherapy to determine which pretreatment clinical, laboratory, and genetic factors were associated with development of life-threatening and disabling (grade 4) bleeding according to the WHO bleeding assessment scale. In order to enable prospective identification of the subset of AML patients in whom enhanced monitoring and supportive care should be focused, we developed a grade 4 bleeding score and tested it in an independent validation cohort.

\section{METHODS}

\section{Patients}

Development cohort. A total of 341 consecutive adult patients ( $\geq 18$ years of age) with newly diagnosed non-APL AML who received initial treatment with intensive induction chemotherapy between August 2014 and March 2020 were included in the development cohort (Dana-Farber/Brigham and Women's Cancer Center, Boston, MA). Patients were excluded who did not receive intensive induction treatment, received previous treatment for AML (excluding hydroxyurea or all-trans retinoic acid) or were previously transplanted with an allogeneic donor for myelodysplastic syndrome or myeloproliferative neoplasm. Among patients aged 18 to 75 years who were not treated with intensive chemotherapy, reasons for refraining from intensive treatment included patient's wish $(n=12)$, poor performance status $(n=11)$, comorbidities $(n=10)$, TP53 mutations $(n=4)$, or other reasons $(n=4)$. No patients were found to be ineligible for intensive chemotherapy because of any grade of bleeding. 
Gene mutations in blood or bone marrow specimens were determined at the time of diagnosis using clinical targeted next generation sequencing of genes recurrently mutated in AML. ${ }^{14}$ Variants were interpreted for pathogenicity as previously described. ${ }^{15-17}$ Most patients ( $n=310,90.9 \%)$ were treated with an anthracycline (daunorubicin or idarubicin) and cytarabine for three and seven days (" $3+7$ "), respectively. The remaining patients $(n=31,9.1 \%)$ received cytarabine and daunorubicin in a liposomal formulation (CPX-351).

Validation cohort. This cohort consisted of 143 non-consecutive adult patients with newly diagnosed non-APL AML who were treated between 2008 and 2020 with intensive induction chemotherapy (Roswell Park Comprehensive Cancer Center, Buffalo, NY). Similar inclusion and exclusion criteria were applied to the validation cohort. Chemotherapy according to the " $3+7$ " regimen was administered to all patients. Gene mutations in blood or bone marrow specimens obtained at the time of diagnosis were determined using targeted next generation sequencing of genes recurrently mutated in AML, as described. ${ }^{16}$

Both cohorts used similar guidelines for supportive care, with prophylactic transfusion typically given for platelets $<10 \times 10^{9} / \mathrm{L}$, fibrinogen $<100 \mathrm{mg} / \mathrm{dL}$, and INR $\geq 2.0$. This study was conducted with the approval of the institutional review boards of both centers.

\section{Clinical data}

Bleeding location and grade were assessed according to the WHO bleeding assessment scale, ${ }^{18}$ where grade 4 bleeding was defined based on the presence of one of the 
following clinical criteria: (1) bleeding with severe hemodynamic instability requiring red blood cell transfusion over routine transfusion needs; (2) fatal bleeding; (3) retinal bleeding with visual impairment; or (4) CNS bleeding with or without neurologic dysfunction. ${ }^{18}$ Bleeding events that occurred between day -14 and day +60 of induction treatment were included to assess early bleeding in newly diagnosed AML patients.

Pretreatment data were collected for all patients (Table 1), as well as data throughout the duration of induction and follow-up status post-induction. Karyotypes were classified based on the European LeukemiaNet (ELN) 2017 risk classification. ${ }^{19}$ Study specific data abstraction of individual patient charts included date of bleeding, location and grade of bleeding, and thrombotic events. Laboratory values for creatinine, albumin, total bilirubin, lactate dehydrogenase (LDH), white blood cell (WBC) count, hemoglobin, and platelet count were obtained from the first day of induction chemotherapy. Coagulation parameters (ie, international normalized ratio of prothrombin time [PT-INR], partial thromboplastin time [PTT], D-dimer, and fibrinogen) were obtained from the first day of induction or closest day to the start of induction treatment within a maximum of seven days prior to start of therapy or prior to bleeding if the bleeding occurred earlier.

\section{Statistical analysis}

Cumulative incidence of grade 4 bleeding was estimated using the Fine and Gray ${ }^{20}$ method, with death without grade 4 bleeding being treated as a competing event. Survival over the first 60 days of induction treatment was calculated with bleeding events as a time-dependent covariate stratified by cohort. No patients were lost to follow-up within the 
medRxiv preprint doi: https://doi.org/10.1101/2021.09.24.21263986; this version posted September 27, 2021. The copyright holder for this preprint (which was not certified by peer review) is the author/funder, who has granted medRxiv a license to display the preprint in perpetuity.

It is made available under a CC-BY-NC-ND 4.0 International license .

first 60 days of induction treatment. Comparisons between the two groups were performed using the Mann-Whitney $\mathrm{U}$ test for continuous variables, whereas the Fisher's exact test was used for categorical variables.

Model development and validation. The grade 4 bleeding score was derived from the development cohort. The following variables were considered for the development of the predictive model: age ( $\geq 60$ vs. $<60$ years), sex (female vs. male), hemoglobin ( $\geq 10$ vs. $<10 \mathrm{~g} / \mathrm{dL}$ ), platelet count ( $>40$ vs. $\leq 40 \times 10^{9} / \mathrm{L}$ ), WBC count ( $\geq 25$ vs. $<25 \times 10^{9} / \mathrm{L}$ ), PT-INR ( $>1.3-1.5$ or $>1.5$ vs. $\leq 1.3$ ), PTT ( $\geq 35$ vs. $<35$ seconds), fibrinogen ( $\geq 200$ vs. $<200 \mathrm{mg} / \mathrm{dL}$ ), D-dimer ( $>4000$ vs. $\leq 4000 \mathrm{ng} / \mathrm{mL}$ ), creatinine ( $\geq 1.5 \mathrm{vs.}<1.5 \mathrm{mg} / \mathrm{dL}$ ), albumin ( $<3$ vs. $\geq 3$ $\mathrm{g} / \mathrm{dL}$ ), total bilirubin ( $>1.2$ vs. $\leq 1.2 \mathrm{mg} / \mathrm{dL}$ ), and LDH ( $\geq 2 \mathrm{vs.}<2 \mathrm{x}$ upper limit of normal), ELN2017 cytogenetic risk classification (intermediate or adverse vs. favorable), and gene mutations (presence vs. absence) found in $\geq 10$ patients (ie, NPM1, DNMT3A, NRAS, TET2, RUNX1, FLT3-ITD, ASXL1, IDH1 IDH2, SRSF2, PTPN11, FLT3-TKD, WT1, BCOR, TP53, KRAS, STAG2, U2AF1, CEBPA, CBL, SF3B1, GATA2, PHF6, KIT, and JAK2). Competing-risk regression analysis according to Fine and Gray ${ }^{20}$ was used to assess variables associated with grade 4 bleeding events. Variables with a significance of $P<0.10$ in the univariate setting were subsequently included in the multivariable model. Forward selection was performed, adding variables with $P<0.10$ and removing those with $P \geq 0.20$ resulting in the final model. Next, integer weights were derived from the coefficients of the independent predictors, which defined the bleeding score. Recursive partitioning was used for defining the optimal cut point of scores resulting in high- and low-risk subgroups. This model was then applied to the external validation cohort using 
medRxiv preprint doi: https://doi.org/10.1101/2021.09.24.21263986; this version posted September 27, 2021. The copyright holder for this preprint (which was not certified by peer review) is the author/funder, who has granted medRxiv a license to display the preprint in perpetuity.

It is made available under a CC-BY-NC-ND 4.0 International license .

competing-risk regression analysis. $P$-values were not adjusted for multiple testing. Analyses were performed with STATA software (Release 16.1; STATA Corporation, College Station, TX) and R (version 3.6.3).

\section{RESULTS}

\section{Bleeding events}

The incidence of grade 4 bleeding was $5.9 \%(n=20)$ in the development cohort and $9.8 \%$ $(n=14)$ in the validation cohort (Figure 1), which were not significantly different $(P=0.123)$. Detailed characteristics of patients with grade 4 bleeding are listed in Table 2. The CNS was involved in $85.0 \%(n=17)$ and $78.6 \%(n=11)$ of patients with grade 4 bleeding complications in the development and validation cohorts, respectively. Therapeutic anticoagulation therapy was administered to patients (development: $n=29$, validation: $n=7$ ) during induction treatment, of whom $n=2$ and $n=1$ experienced grade 4 bleeding, respectively. The incidence of grade 4 bleeding was not significantly different between patients receiving " $3+7$ " vs. CPX-351 (5.5\% vs. $9.7 \%$, respectively, $P=0.343)$ in the development cohort. Patients with grade 4 bleeding events had worse survival during the 60 days after start of induction treatment compared with patients without grade 4 bleeding stratified by cohort (hazard ratio $8.12 ; 95 \%$ confidence interval [CI]: 4.22-15.62, $P<0.001)$.

\section{Bleeding score}

Model development. A total of ten variables were associated with grade 4 bleeding events in the development cohort by univariate competing-risk regression analysis and 
medRxiv preprint doi: https://doi.org/10.1101/2021.09.24.21263986; this version posted September 27, 2021. The copyright holder for this preprint (which was not certified by peer review) is the author/funder, who has granted medRxiv a license to display the preprint in perpetuity.

It is made available under a CC-BY-NC-ND 4.0 International license .

were considered in the multivariable model (Table 3). Two patients were excluded in the final model because of missing data. Platelet count of $\leq 40 \times 10^{9} / \mathrm{L}$ and PT-INR of $>1.3-1.5$ and $>1.5$ were the only independent factors associated with grade 4 bleeding events (Table 3). The estimated coefficients $(1.29,2.04$, and 3.11 , respectively) of these predictors were divided by two and rounded to the nearest integer resulting in the grade 4 bleeding score (Figure 2A). The risk score ranges from 0 to 3 points and the incidence of grade 4 bleeding increased with higher scores (Figure 2B). The cut-off was found to be optimal at $>1$ point for high-risk patients versus $\leq 1$ point for low-risk patients. Using this score, $42(12.3 \%)$ patients were considered high-risk for grade 4 bleeding in the development cohort, whereas 297 (87.1\%) patients had low-risk (Figure 2B). The cumulative incidence of grade 4 bleeding at day 60 was higher among patients in the high-risk subgroup compared with those in the low-risk subgroup ( $31 \pm 7 \%$ vs. $2 \pm 1 \%$, $P<0.001$, Figure 2C). The sensitivity and specificity of the model for prediction of grade 4 bleeding were $31.0 \%$ and $97.6 \%$, respectively. WHO grade 2 or 3 bleeding events were most frequently observed in gastrointestinal $(n=34,10.0 \%)$, and genitourinary $(n=31$, 9.1\%) sites (Figure 1) and, as expected, were not predicted by the bleeding score (subdistribution hazard ratio [SHR] 1.02; 95\% Cl: 0.49-2.16, $P=0.947$ ). Seven patients who experienced grade 4 bleeding events had a low pretreatment bleeding score. Four developed laboratory evidence of DIC-like coagulopathy after start of treatment, two had mechanical/procedural-related bleeding, and one had concurrent multi-organ failure without DIC. 
Model validation. Patients in the validation cohort were older than patients in the development cohort (64 vs. 61 years, $P=0.001$ ), and harbored more high-risk AML features, including higher frequency of adverse risk cytogenetics, increased frequency of TP53 mutations, and decreased frequency of NPM1 mutations (Table 1). Additionally, baseline platelet and WBC counts were higher in the validation cohort compared with the development cohort, whereas PT-INR and D-dimer were similarly distributed.

In this cohort, $24(16.8 \%)$ and $119(83.2 \%)$ patients had high- and low-risk of grade 4 bleeding, respectively. The bleeding score significantly differentiated patients in the validation cohort with high- versus low-risk of grade 4 bleeding (cumulative incidence at day 60: $25 \pm 9 \%$ vs. $7 \pm 2 \%$, respectively, $P=0.008$, Figure $2 B-C$ ). The sensitivity and specificity for the prediction of grade 4 bleeding in the validation cohort were $25.0 \%$ and $93.2 \%$, respectively. We explored the inclusion of $D$-dimer in this cohort because of higher availability ( $n=105,73.4 \%)$, which did not improve the predictive capacity of the bleeding score (SHR 1.90, 95\% Cl: 0.91-3.96, $P=0.089$ ). As in the development cohort, the bleeding score did not predict grade 2 or 3 bleeding events (SHR $1.28,95 \% \mathrm{Cl}$ : $0.65-$ $2.51, P=0.481)$.

\section{DIC in patients with high bleeding risk}

Our results raised the possibility that pre-treatment, disease-associated DIC is the biological driver of bleeding risk in AML. Therefore, we evaluated the association between bleeding score and other laboratory hallmarks of DIC that reflect consumption of coagulation factors and hyperfibrinolysis, as well as other clinical manifestations of DIC, 
including thrombosis (Table 4). The high-risk subgroup had significantly prolonged median PTT (development 41.6 vs. 32.4 seconds, $P<0.001$; validation: 34.3 vs 30.7 seconds, $P=0.005$ ) and significantly elevated median D-dimer levels (development: $>4000$ vs. $1526 \mathrm{ng} / \mathrm{mL}, P=0.010$; validation: 6618 vs. $1390 \mathrm{ng} / \mathrm{mL}, P=0.004$ ) compared with the low-risk subgroup. Hypofibrinogenemia of $<100 \mathrm{mg} / \mathrm{dL}$ was observed in $0.3 \%$ and $2.8 \%$ in the development and validation cohort, respectively. Median fibrinogen levels were not significantly different between high- versus low-risk patients in the development cohort (370 vs. $374 \mathrm{mg} / \mathrm{dL}$, respectively, $P=0.429$ ), but were lower in the validation cohort (356 vs. $433 \mathrm{mg} / \mathrm{dL}, P=0.031$ ).

Since DIC has also been linked to thrombosis in AML patients, ${ }^{21}$ we analyzed the association of bleeding score with thrombosis during treatment. Non-catheter associated thrombotic events within the first 60 days of induction treatment were observed in $4.7 \%$ $(n=16)$ and $4.2 \%(n=6)$ of patients in the development and validation cohort, respectively, including deep venous thrombosis $(n=10,3.0 \%$ and $n=5,3.5 \%)$ and pulmonary embolism $(n=5,1.5 \%$ and $n=1,0.7 \%)$. A high-risk bleeding score was predictive of non-catheter associated thrombosis in the development cohort (SHR 4.52, $95 \% \mathrm{Cl}: 1.65-12.33$, $P=0.003$ ) and validation cohort (SHR 5.09; 95\%Cl: $1.05-24.78, P=0.044)$; this association was independent of baseline WBC count and $\mathrm{LDH}$, highlighting the dual risk of hemorrhage and thrombosis in patients with DIC-like coagulopathy. In contrast, catheterassociated thromboses, which are provoked by placement of indwelling central venous catheters, occurred in $9.1 \%(n=31)$ and $7.0 \%(n=10)$ of patients in the development and 
medRxiv preprint doi: https://doi.org/10.1101/2021.09.24.21263986; this version posted September 27, 2021. The copyright holder for this preprint (which was not certified by peer review) is the author/funder, who has granted medRxiv a license to display the preprint in perpetuity.

It is made available under a CC-BY-NC-ND 4.0 International license .

validation cohorts, respectively, and were not associated with a high-risk bleeding score (SHR 2.19; 95\%Cl: 0.94-5.11, $P=0.069$, and SHR 2.17; 95\%Cl: 0.57-8.20, $P=0.254$ ).

\section{High bleeding score is associated with proliferative AML}

To identify factors associated with high versus low bleeding scores, we compared patient and disease characteristics between the two risk groups in both cohorts (Table 4). Patients with a high bleeding score had significantly higher median WBC counts compared with patients with a low bleeding score (development: 18.3 vs. $5.8 \times 10^{9} / \mathrm{L}$, $P<0.001$; validation: 40.4 vs. $\left.6.6 \times 10^{9} / \mathrm{L}, P<0.001\right)$. Similarly, baseline $\mathrm{LDH}$ was significantly higher in high- versus low-risk patients (development: 752 vs. $312 \mathrm{U} / \mathrm{L}$, $P<0.001$; validation: 2130 vs. $833 \mathrm{U} / \mathrm{L}, P<0.001)$. Somatic gene mutations which have been previously associated with proliferative AML or hyperleukocytosis, ${ }^{22}$ including $F L T 3$, NPM1, or drivers of activated RAS/MAPK signaling (NRAS, KRAS, PTPN11, CBL) were not associated with the grade 4 bleeding score in either cohort. Bleeding risk was also not significantly associated with any other disease-related or patient-related variables, including ELN cytogenetic risk, age, or sex.

\section{DISCUSSION}

Predicting the risk of treatment complications is central to the clinical care of patients with newly diagnosed AML. Quantitative scoring systems can predict overall risk of early mortality after intensive AML chemotherapy, but do not predict the development of specific life-threatening complications and do not provide guidance on risk mitigation 
strategies. Even among patients who are "fit" based on conceptual or quantitative criteria, bleeding remains a major cause of early morbidity and mortality.

In this study, we identified a subset of non-APL AML patients with a DIC-like coagulopathy who had an elevated risk of developing life-threatening or disabling bleeding early during induction treatment. We present a simple predictive scoring system which was developed in a cohort of consecutively treated real-world AML patients and validated in an independent cohort. Most AML patients had a low bleeding score, associated with a $2 \%$ cumulative incidence of early bleeding. In contrast, $12 \%$ of patients had a high bleeding score and a $31 \%$ cumulative incidence of early bleeding despite receiving standard of care inpatient monitoring and supportive measures.

Patients with high grade 4 bleeding score had the characteristic clinical features of DIC, including an increased incidence of both bleeding and non-catheter associated thrombosis in the context of consumptive coagulopathy and decreased platelet count. ${ }^{23,24}$ However, unlike the coagulopathy observed in APL and B-cell acute lymphoblastic leukemia, the coagulopathy in newly diagnosed non-APL AML was not associated with severe hypofibrinogenemia (fibrinogen levels $<100 \mathrm{mg} / \mathrm{dL}$, as defined by the International Society on Thrombosis and Haemostasis-DIC scoring system ${ }^{25}$ ) and hypofibrinogenemia did not correlate with excess bleeding risk in patients with a high bleeding score. In addition, although we were not able to interrogate the added value of D-dimer as a risk factor for grade 4 bleeding due to missing data in the development cohort, we found that D-dimer did not improve the bleeding score in the independent validation cohort. Together 
this suggests that hyperfibrinolysis is not an independent risk factor for grade 4 bleeding in AML patients and may not be a major component of the coagulopathy of non-APL AML.

Bleeding is a major cause associated with early mortality of intensive AML induction treatment, ${ }^{2}$ and our study shows that DIC-like coagulopathy is a clinically significant driver of life-threatening WHO grade 4 bleeding events in AML patients. In contrast, coagulation abnormalities were not associated with development of grade 2-3 bleeding, indicating that these less severe events are more clinically heterogeneous and biologically multifactorial. We found that factors previously linked with different grades of bleeding, including age, sex, hemoglobin level, hepatic and renal function, and WBC count were not independently associated with an increased risk of grade 4 bleeding in our study. ${ }^{10,11,26,27}$ Notably, several patients had a low baseline bleeding score but experienced grade 4 bleeding events after developing laboratory DIC-like coagulopathy during treatment. Future studies may refine our model by incorporating serial assessment of coagulation labs in order to quantify dynamic bleeding risk evolution during treatment.

The results of this study provide a pre-treatment tool to identify patients at high-risk for grade 4 bleeding. Although treatment of AML should begin promptly, initiation of induction chemotherapy must be balanced with delay to optimize organ function, manage coagulopathy, and improve overall condition in order to minimize treatment-related complications..$^{28,29}$ Several strategies could be employed to mitigate the risk of grade 4 bleeding in patients with a high bleeding score, including pre-induction correction of DICrelated laboratory coagulopathy, reduction of proliferative disease, and stringent clinical 
and laboratory monitoring. There are limited data to support evidence-based guidelines for supportive hemostatic strategies in patients with DIC. Moreover, the typical prophylactic platelet transfusion threshold of $<10 \times 10^{9} / \mathrm{L}$ might not be effective in $\mathrm{AML}$ patients with DIC-like coagulopathy. Consensus recommendations for DIC management have prioritized platelet transfusions and replacement of coagulation factors with freshfrozen plasma or prothrombin complex concentrate. ${ }^{30}$ These recommendations could also apply to the high-risk subset of AML patients with a DIC-related coagulopathy as defined in this study to maintain a platelet count of $>20-30 \times 10^{9} / \mathrm{L}$ in patients without bleeding, and a higher threshold of $>50 \times 10^{9} / \mathrm{L}$ in high-risk patients with concurrent bleeding events. However, AML-specific thresholds may be unique given the multifactorial contributions to thrombocytopenia, including disease-related marrow dysfunction, treatment-related myelosuppression, infections, sepsis, and coagulation abnormalities following anthracycline-based intensive induction chemotherapy. ${ }^{31}$ Patients with proliferative $\mathrm{AML}$ are also at increased risk for DIC-related coagulopathy arising from high levels of procoagulants triggering the extrinsic coagulation pathway. ${ }^{23,31,32}$ Consequently, cytoreduction with hydroxyurea prior to initiating induction chemotherapy may normalize the activated coagulation pathway and improve safety of treatment in this high-risk population. Altogether, patients at high-risk for grade 4 bleeding need careful clinical and laboratory monitoring after treatment initiation, with emphasis on early diagnosis and interventions to minimize bleeding complications.

In conclusion, we developed and independently validated a novel and simple tool which identifies AML patients with a clinical phenotype of DIC-like coagulopathy who are at high- 
medRxiv preprint doi: https://doi.org/10.1101/2021.09.24.21263986; this version posted September 27, 2021. The copyright holder for this preprint (which was not certified by peer review) is the author/funder, who has granted medRxiv a license to display the preprint in perpetuity.

It is made available under a CC-BY-NC-ND 4.0 International license .

risk of grade 4 bleeding. In such patients, assertive supportive care aimed at reversing the coagulopathy and reducing proliferative disease may decrease the incidence of lifethreatening bleeding events and reduce the risk of early mortality during induction treatment. 


\section{CONTRIBUTORS}

J.V. and R.C.L designed the study, analyzed the data, and wrote the manuscript; J.V., M.P., J.E.H., R.S.V., A.C., K.M.C., O.W., E.A.G., J.E.T., R.M.S., D.J.D., M.R.L., E.S.W. and R.C.L. provided patient data; J.V., M.P., J.E.H., A.C., K.M.C., O.W. and R.C.L. collected and assembled clinical, laboratory and genetic data; J.V., Y.F., D.N., R.C.L. conceived the statistical plan, and performed the statistical analysis; J.V., M.P., Y.F., D.N., M.R.L., E.S.W. and R.C.L interpreted data and contributed to research discussion; and all authors reviewed the manuscript and approved the submission. Authors J.V., Y.F., D.N., and R.C.L. had full access to all data.

\section{ACKNOWLEDGMENTS}

This work was supported by grants from the National Institutes of Health K08CA204734 (R.C.L.) and T32HL066987 (R.B.), American Society of Hematology - Amos Medical Faculty Development Program Award (R.B.), the Edward P. Evans Foundation, Rubicon fellowship from the Netherlands Organization for Scientific Research (J.V), Erasmus Medical Center Foundation-Daniel den Hoed (J.V.), Rene Vogels stipend (J.V.), and the DFCI Hematologic Malignancies Data Repository. 
medRxiv preprint doi: https://doi.org/10.1101/2021.09.24.21263986; this version posted September 27, 2021. The copyright holder for this preprint (which was not certified by peer review) is the author/funder, who has granted medRxiv a license to display the preprint in perpetuity.

It is made available under a CC-BY-NC-ND 4.0 International license .

\section{REFERENCES}

1. Ferrara F, Schiffer CA. Acute myeloid leukaemia in adults. Lancet. 2013;381(9865):484-495.

2. Ho G, Jonas BA, Li Q, et al. Early mortality and complications in hospitalized adult Californians with acute myeloid leukaemia. Br. J. Haematol. 2017;177(5):791-799.

3. Schlenk RF, Paschka P, Krzykalla J, et al. Gemtuzumab Ozogamicin in -Mutated Acute Myeloid Leukemia: Early Results From the Prospective Randomized AMLSG 09-09 Phase III Study. J. Clin. Oncol. 2020;38(6):623-632.

4. Bassan R, Intermesoli $\mathrm{T}$, Masciulli $\mathrm{A}$, et al. Randomized trial comparing standard vs sequential high-dose chemotherapy for inducing early $\mathrm{CR}$ in adult $\mathrm{AML}$. Blood Adv. 2019;3(7):1103-1117.

5. Braess J, Amler S, Kreuzer K-A, et al. Sequential high-dose cytarabine and mitoxantrone (SHAM) versus standard double induction in acute myeloid leukemia-a phase 3 study. Leukemia. 2018;32(12):2558-2571.

6. Lee J-H, Kim H, Joo Y-D, et al. Prospective Randomized Comparison of Idarubicin and HighDose Daunorubicin in Induction Chemotherapy for Newly Diagnosed Acute Myeloid Leukemia. J. Clin. Oncol. 2017;35(24):2754-2763.

7. Walter RB, Othus M, Borthakur G, et al. Prediction of early death after induction therapy for newly diagnosed acute myeloid leukemia with pretreatment risk scores: a novel paradigm for treatment assignment. J. Clin. Oncol. 2011;29(33):4417-4423.

8. Palmieri R, Othus M, Halpern AB, et al. Accuracy of SIE/SIES/GITMO Consensus Criteria for Unfitness to Predict Early Mortality After Intensive Chemotherapy in Adults With AML or Other High-Grade Myeloid Neoplasm. J. Clin. Oncol. 2020;38(35):4163-4174.

9. Ferrara F, Barosi G, Venditti A, et al. Consensus-based definition of unfitness to intensive and non-intensive chemotherapy in acute myeloid leukemia: a project of SIE, SIES and GITMO group on a new tool for therapy decision making. Leukemia. 2013;27(5):997-999. 
10. Dayyani F, Mougalian SS, Naqvi K, et al. Prediction model for mortality after intracranial hemorrhage in patients with leukemia. Am. J. Hematol. 2011;86(7):546-549.

11. Kim H, Lee J-H, Choi S-J, et al. Risk score model for fatal intracranial hemorrhage in acute leukemia. Leukemia. 2006;20(5):770-776.

12. Chen C-Y, Tai C-H, Tsay W, Chen P-Y, Tien H-F. Prediction of fatal intracranial hemorrhage in patients with acute myeloid leukemia. Ann. Oncol. 2009;20(6):1100-1104.

13. Just Vinholt P, Højrup Knudsen G, Sperling S, Frederiksen H, Nielsen C. Platelet function tests predict bleeding in patients with acute myeloid leukemia and thrombocytopenia. Am. J. Hematol. 2019;94(8):891-901.

14. Kluk MJ, Lindsley RC, Aster JC, et al. Validation and Implementation of a Custom NextGeneration Sequencing Clinical Assay for Hematologic Malignancies. J. Mol. Diagn. 2016;18(4):507-515.

15. Lindsley RC, Mar BG, Mazzola E, et al. Acute myeloid leukemia ontogeny is defined by distinct somatic mutations. Blood. 2015;125(9):1367-1376.

16. Lindsley RC, Saber W, Mar BG, et al. Prognostic Mutations in Myelodysplastic Syndrome after Stem-Cell Transplantation. N. Engl. J. Med. 2017;376(6):536-547.

17. Papaemmanuil E, Gerstung M, Bullinger L, et al. Genomic Classification and Prognosis in Acute Myeloid Leukemia. N. Engl. J. Med. 2016;374(23):2209-2221.

18. Slichter SJ, Kaufman RM, Assmann SF, et al. Dose of prophylactic platelet transfusions and prevention of hemorrhage. N. Engl. J. Med. 2010;362(7):600-613.

19. Döhner H, Estey E, Grimwade D, et al. Diagnosis and management of AML in adults: 2017 ELN recommendations from an international expert panel. Blood. 2017;129(4):424-447.

20. Fine JP, Gray RJ. A Proportional Hazards Model for the Subdistribution of a Competing Risk. Journal of the American Statistical Association. 1999;94(446):496-509. 
medRxiv preprint doi: https://doi.org/10.1101/2021.09.24.21263986; this version posted September 27, 2021. The copyright holder for this preprint (which was not certified by peer review) is the author/funder, who has granted medRxiv a license to display the preprint in perpetuity.

It is made available under a CC-BY-NC-ND 4.0 International license .

21. Libourel EJ, Klerk CPW, van Norden $\mathrm{Y}$, et al. Disseminated intravascular coagulation at diagnosis is a strong predictor for thrombosis in acute myeloid leukemia. Blood. 2016;128(14):1854-1861.

22. Röllig C, Ehninger G. How I treat hyperleukocytosis in acute myeloid leukemia. Blood. 2015;125(21):3246-3252.

23. Falanga A, Marchetti M, Vignoli A. Coagulation and cancer: biological and clinical aspects. J. Thromb. Haemost. 2013;11(2):223-233.

24. Levi M, Scully M. How I treat disseminated intravascular coagulation. Blood. 2018;131(8):845-854.

25. Taylor FB Jr, Toh CH, Hoots WK, et al. Towards definition, clinical and laboratory criteria, and a scoring system for disseminated intravascular coagulation. Thromb. Haemost. 2001;86(5):1327-1330.

26. Decousus H, Tapson VF, Bergmann J-F, et al. Factors at admission associated with bleeding risk in medical patients: findings from the IMPROVE investigators. Chest. 2011;139(1):69_ 79.

27. Patell R, Gutierrez A, Rybicki L, Khorana AA. Identifying predictors for bleeding in hospitalized cancer patients: A cohort study. Thromb. Res. 2017;158:38-43.

28. Bertoli S, Bérard E, Huguet F, et al. Time from diagnosis to intensive chemotherapy initiation does not adversely impact the outcome of patients with acute myeloid leukemia. Blood. 2013;121(14):2618-2626.

29. Röllig C, Kramer M, Schliemann C, et al. Does time from diagnosis to treatment affect the prognosis of patients with newly diagnosed acute myeloid leukemia? Blood. 2020;136(7):823-830.

30. Squizzato A, Hunt BJ, Kinasewitz GT, et al. Supportive management strategies for disseminated intravascular coagulation. An international consensus. Thromb. Haemost. 2016;115(5):896-904. 
medRxiv preprint doi: https://doi.org/10.1101/2021.09.24.21263986; this version posted September 27, 2021. The copyright holder for this preprint (which was not certified by peer review) is the author/funder, who has granted medRxiv a license to display the preprint in perpetuity. It is made available under a CC-BY-NC-ND 4.0 International license .

31. Barbui T, Falanga A. Disseminated intravascular coagulation in acute leukemia. Semin. Thromb. Hemost. 2001;27(6):593-604.

32. Dixit A, Chatterjee $\mathrm{T}$, Mishra $\mathrm{P}$, et al. Disseminated intravascular coagulation in acute leukemia at presentation and during induction therapy. Clin. Appl. Thromb. Hemost. 2007;13(3):292-298. 
medRxiv preprint doi: https://doi.org/10.1101/2021.09.24.21263986; this version posted September 27, 2021. The copyright holder for this preprint (which was not certified by peer review) is the author/funder, who has granted medRxiv a license to display the preprint in perpetuity.

It is made available under a CC-BY-NC-ND 4.0 International license .

\section{Figure legends}

Figure 1. Bleeding events WHO grade 2 and higher in the development and validation cohorts.

This plot shows bleeding events by location, as labeled on the left. Bleeding events are depicted by the colored bars, and each column represents 1 of the 168 patients with a WHO grade 2 bleeding or higher. Colors reflect the bleeding grade, as labeled on the top.

Figure 2. Development and validation of grade 4 bleeding score

(A) Variables and their assigned points of the grade 4 bleeding score result in two subgroups of low- and high-risk for grade 4 bleeding. (B) Frequency of grade 4 bleeding by risk score in the development and validation cohort. The number of patients by bleeding score are shown in the table below. (C) Cumulative incidence of grade 4 bleeding by risk group of the bleeding score, with death considered as a competing event. Time is measured from the first day of induction chemotherapy, whereas events occurring in the 14 days prior to the start of induction treatment are counted at day zero. 
Figure 1

medRxiv preprint doi: https://doi.org/10.1101/2021.09.24.21263986; this version posted September 27, 2021. The copyright holder for this preprint (which was not certified by peer review) is the author/funder, who has granted medPxiv a license to display the preprint in perpetuit
Validation cohort

Maximum grade

Grade 4
$5.9 \%$

$$
\text { Grade } 3
$$
t is made available unde Validation cohort

\section{CNS}

$\begin{array}{ll}\text { 을 } & \text { CNS (retinal) } \\ \text { 융 Gastrointestinal } & \\ \text { 으 Pulmonary } & \end{array}$

||||||||||||
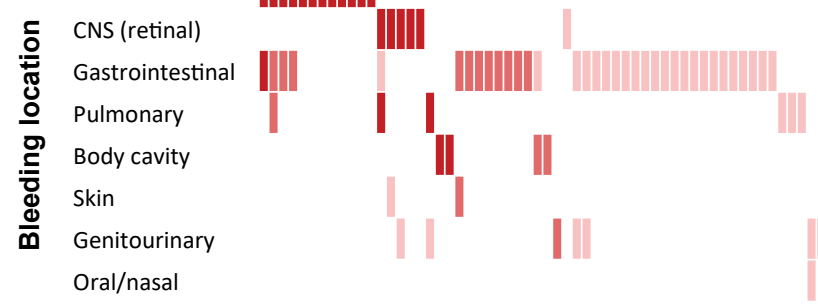

\begin{tabular}{c} 
Grade 4 \\
$9.8 \%$ \\
\hline
\end{tabular}

Grade 3

$16.8 \%$

Grade 2

$29.3 \%$

IIIIIIII

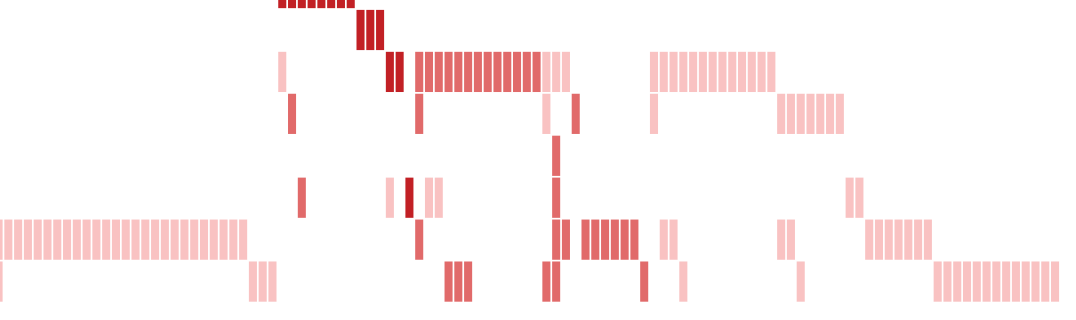


Figure 2

medRxiv preprint doi: https://doi.org/10.1101/2021.09.24.21263986; this version posted September 27, 2021. The copyright holder for this

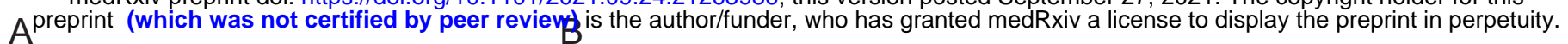

Grade 4

Bleeding Score

\begin{tabular}{|c|c|}
\hline $\begin{array}{l}\text { Platelets, } x \\
\quad>40 \\
\quad \leq 40\end{array}$ & $\begin{array}{l}10^{9} / \mathrm{L} \\
=0 \\
=1\end{array}$ \\
\hline $\begin{array}{l}\text { PT-INR } \\
\quad \leq 1.3 \\
>1.3-1.5 \\
>1.5\end{array}$ & $\begin{array}{l}=0 \\
=1 \\
=2\end{array}$ \\
\hline $\begin{array}{l}\text { Risk group } \\
\text { Low } \\
\text { High }\end{array}$ & $\begin{array}{l}\text { s } \\
=0-1 \text { points } \\
=2-3 \text { points }\end{array}$ \\
\hline
\end{tabular}

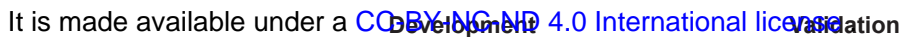

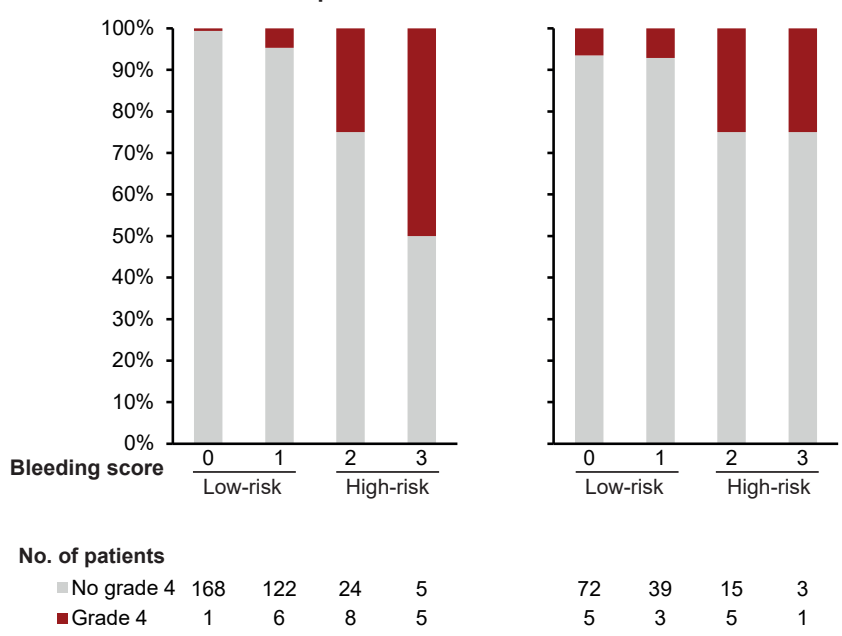

C

Competing risk regression of grade 4 bleeding by risk groups
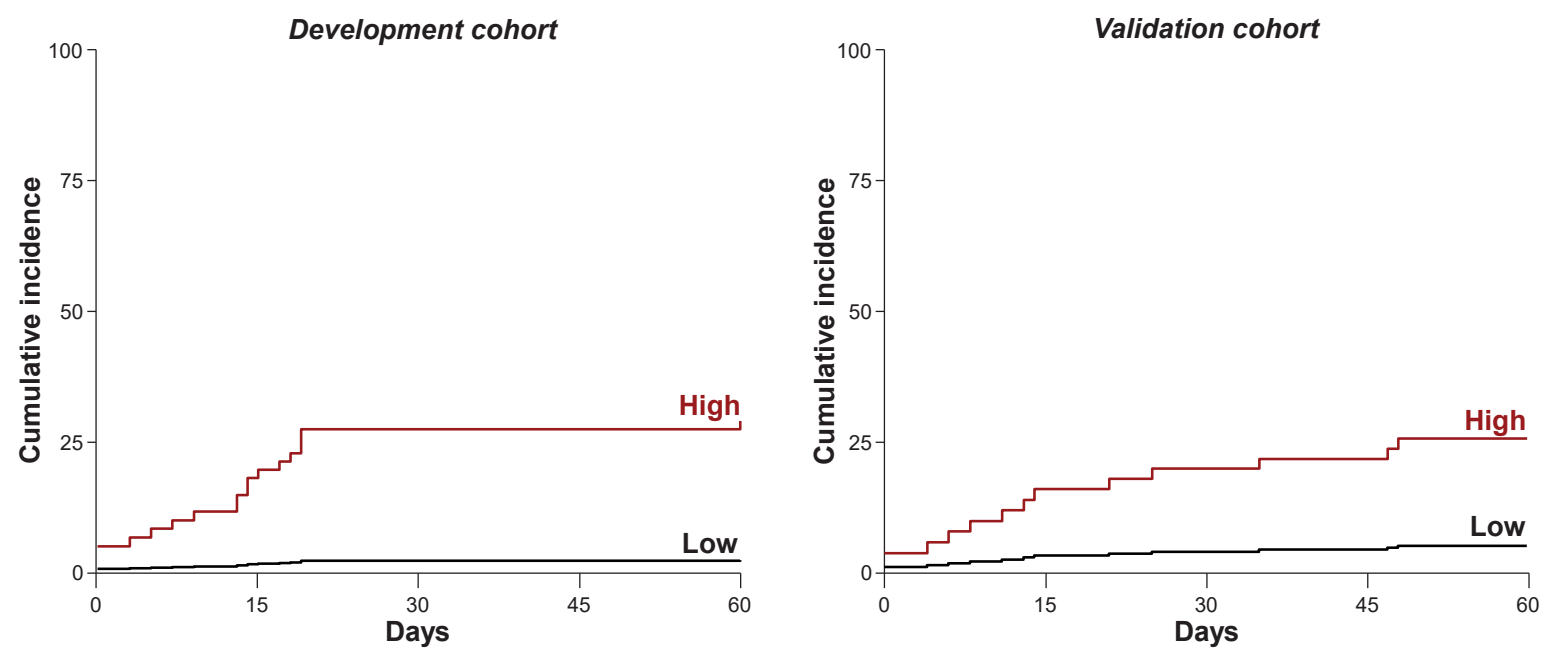
It is made available Dreverapheat -NC-ND 4.0 International licensalidation

cohort

cohort

$P$ value*

Age, years; median (range)

341

61

(19-76)

341

Sex

Male

Female

ELN2017 cytogenetic risk group

Favorable

Intermediate

Adverse

Somatic mutations, presence

NPM1

DNMT3A

NRAS

RUNX1

TET2

ASXL1

FLT3-ITD

IDH2

SRSF2

IDH1

TP53

FLT3-TKD

Hemoglobin, g/dL

Platelets, x109/L

WBC, $x 109 / L$

Coagulation, median (IQR)

\section{PT-INR}

PTT, sec

Fibrinogen, mg/dL

D-dimer, $\mathrm{ng} / \mathrm{mL}$

Chemistry, median (IQR)

Creatinine, $\mathrm{mg} / \mathrm{dL}$

Albumin, g/dL

Bilirubin, $\mathrm{mg} / \mathrm{dL}$

LDH, U/L†

$183 \quad 54 \%$

$158 \quad 46 \%$

337

$\begin{array}{cc}40 & 12 \% \\ 233 & 68 \% \\ 64 & 19 \%\end{array}$

341

$\begin{array}{ll}91 & 27 \% \\ 74 & 22 \% \\ 61 & 18 \% \\ 52 & 15 \% \\ 53 & 16 \% \\ 46 & 13 \% \\ 51 & 15 \% \\ 39 & 11 \% \\ 37 & 11 \% \\ 40 & 12 \% \\ 23 & 7 \% \\ 32 & 9 \%\end{array}$

Complete blood count, median (IQR) $(n=341)$

$(n=143)$

$n$

143

64

(20-85)

143

140

$\begin{array}{ll}88 & 62 \% \\ 55 & 38 \%\end{array}$

$\begin{array}{cc}13 & 9 \% \\ 79 & 56 \% \\ 48 & 34 \%\end{array}$

143

$17 \quad 12 \%$

.002

$\begin{array}{lll}25 & 17 \% & .035 \\ 23 & 16 \% & .173 \\ 24 & 17 \% & .896\end{array}$

$30 \quad 21 \% \quad .144$

$20 \quad 14 \% \quad .781$

$25 \quad 17 \% \quad .262$

$20 \quad 14 \% \quad .888$

$22 \quad 15 \% \quad .233$

$23 \quad 16 \% \quad .130$

$13 \quad 9 \% \quad .430$

$26 \quad 18 \% \quad<.001$

.412

Abbreviations: ELN, European LeukemiaNET; IQR, interquartile range; LDH thromboplastin time; WBC, white blood cells; WHO, world health organization.

* Comparisons were adjusted to the upper limit of normal where appropriate

† The upper limit of normal for LDH was $225 \mathrm{U} / \mathrm{L}$ in the development cohort and $618 \mathrm{U} / \mathrm{L}$ in the validation cohort 
medRxiv preprint doi: https://doi.org/10.1101/2021.09.24.21263986; this version posted September 27, 2021. The copyright holder for this preprint (which was not certified by peer review) is the author/funder, who has granted medRxiv a license to display the preprint in perpetuity.

It is made available under a CC-BY-NC-ND 4.0 International license .

Table 2. Characteristics of patients with grade 4 bleeding

\begin{tabular}{|c|c|c|c|c|c|c|c|c|c|c|c|c|c|c|}
\hline Cohort & $\begin{array}{l}\text { Patient } \\
\text { ID }\end{array}$ & $\begin{array}{c}\text { Age at } \\
\text { induction }\end{array}$ & Sex & WHO bleeding location & $\begin{array}{c}\text { Bleeding } \\
\text { onset } \\
\text { (days) }\end{array}$ & WBC & Platelets & PT-INR & PTT & D-dimer & $\begin{array}{c}\text { Total } \\
\text { bilirubin }\end{array}$ & Albumin & LDH $^{*}$ & $\begin{array}{r}\text { Survival } \\
\text { at day+60 }\end{array}$ \\
\hline D & 7 & $60-64$ & $\mathrm{~F}$ & CNS & 9 & 2.6 & 29 & 1.6 & 43.7 & $>4000$ & 0.5 & 2.4 & 1174 & $\dagger$ \\
\hline D & 18 & $65-69$ & M & CNS + gastrointestinal & 5 & 166.4 & 79 & 2.2 & 42.1 & & 0.6 & 3.1 & 2151 & $\dagger$ \\
\hline D & 40 & $60-64$ & $\mathrm{~F}$ & CNS (retinal with symptoms) & 19 & 18.2 & 34 & 1.6 & & 3786 & 1.2 & 3.5 & 684 & \\
\hline D & 41 & 70-74 & M & CNS & 3 & 17.4 & 42 & 1.4 & 41.0 & & 0.4 & 3.5 & 467 & \\
\hline D & 62 & $55-59$ & $\mathrm{~F}$ & CNS & 14 & 16.3 & 5 & 1.5 & 34.9 & & 1.5 & 2.8 & 1699 & $t$ \\
\hline D & 99 & $50-54$ & $\mathrm{~F}$ & CNS & -14 & 6.4 & 25 & 1.4 & 44.9 & & 0.5 & 2.4 & 372 & \\
\hline D & 100 & $55-59$ & $\mathrm{~F}$ & CNS & 17 & 12.9 & 98 & 1.4 & 48.3 & $>4000$ & 0.6 & 2.8 & 850 & $\dagger$ \\
\hline D & 121 & $55-59$ & $\mathrm{~F}$ & CNS & 19 & 5.5 & 8 & 1.4 & 63.3 & & 0.6 & 3.4 & 803 & \\
\hline D & 130 & $45-59$ & $\mathrm{~F}$ & CNS (retinal with symptoms) & 0 & 37.4 & 10 & 1.6 & 43.5 & $>4000$ & 0.8 & 3.5 & 647 & \\
\hline D & 139 & $25-29$ & M & CNS (retinal with symptoms) + pulmonary & -5 & 232.7 & 22 & 1.5 & 36.1 & $>4000$ & 1.4 & 3.0 & 806 & $\dagger$ \\
\hline D & 166 & $20-24$ & $\mathrm{~F}$ & CNS (retinal with symptoms) & 14 & 12.1 & 33 & 1.5 & 33.0 & 1158 & 0.5 & 3.5 & 309 & \\
\hline D & 176 & $60-64$ & M & CNS & 13 & 28.9 & 34 & 1.6 & 61.1 & $>4000$ & 2.2 & 2.7 & 2501 & $\dagger$ \\
\hline D & 190 & 30-34 & $\mathrm{F}$ & CNS & 13 & 16.3 & 21 & 1.5 & 34.7 & $>4000$ & 0.4 & 2.8 & 751 & t \\
\hline D & 195 & $55-59$ & M & CNS (retinal with symptoms) & -4 & 90.9 & 16 & 1.2 & 29.4 & $>4000$ & 0.8 & 3.7 & 2255 & \\
\hline D & 237 & $65-69$ & M & CNS & 19 & 1.3 & 192 & 1.2 & 37.0 & & & & 149 & \\
\hline D & 240 & $50-54$ & M & Body cavity & 60 & 0.8 & 27 & 1.2 & & & 0.9 & 3.7 & 163 & \\
\hline D & 251 & $30-34$ & $\mathrm{~F}$ & CNS & 7 & 30.8 & 40 & 1.1 & 27.2 & & 0.2 & 3.8 & 439 & $\dagger$ \\
\hline D & 268 & $55-59$ & M & CNS & 15 & 6.1 & 32 & 1.1 & 37.7 & & 0.4 & 4.4 & 473 & \\
\hline D & 280 & $35-39$ & $\mathrm{~F}$ & Pulmonary & 0 & 38.8 & 28 & 1.7 & 41.5 & & 0.5 & 3.5 & 1836 & $\dagger$ \\
\hline D & 336 & $65-69$ & M & Body cavity & 18 & 107.3 & 50 & 2.1 & 47.4 & & 0.9 & 2.1 & 588 & $t$ \\
\hline $\mathrm{v}$ & 10 & $20-24$ & M & CNS (retinal with symptoms) & 14 & 19.2 & 147 & 1.1 & 30.6 & 706 & 0.3 & 3.9 & 1066 & \\
\hline V & 26 & $55-59$ & $\mathrm{~F}$ & CNS & 8 & 67.5 & 84 & 1.8 & 25.0 & $>20000$ & 0.1 & 3.6 & 2338 & \\
\hline v & 30 & $40-44$ & M & CNS & -3 & 18.3 & 7 & 2.4 & 28.9 & 16358 & 2.3 & 3.3 & 22084 & \\
\hline $\mathrm{v}$ & 58 & $55-59$ & M & CNS & 21 & 41.4 & 58 & 1.3 & 30.0 & 16041 & 0.7 & 3.6 & 4489 & \\
\hline $\mathrm{v}$ & 97 & $65-69$ & M & CNS & 35 & 109.8 & 156 & 1.1 & 27.5 & 1720 & 0.5 & 4.8 & 2063 & \\
\hline $\mathrm{v}$ & 117 & $65-69$ & $\mathrm{~F}$ & Musculoskeletal & 47 & 166.4 & 47 & 1.6 & 51.8 & & 0.6 & 3.4 & 2502 & $\dagger$ \\
\hline $\mathrm{v}$ & 121 & $65-69$ & M & CNS & 25 & 41.6 & 24 & 1.4 & 34.3 & & 1.2 & 2.7 & 1135 & $\dagger$ \\
\hline $\mathrm{v}$ & 124 & $75-79$ & M & Gastrointestinal & 48 & 56.2 & 40 & 1.1 & 35.8 & 2370 & 0.6 & 3.0 & 754 & \\
\hline v & 127 & $65-69$ & $\mathrm{~F}$ & CNS & 11 & 12.2 & 49 & 1.9 & 45.1 & $>20000$ & 0.6 & 4.4 & 13927 & \\
\hline $\mathrm{v}$ & 130 & $65-69$ & M & CNS (retinal with symptoms) & 4 & 0.6 & 23 & 1.4 & 43.4 & 1960 & 1.3 & 2.9 & 988 & \\
\hline v & 135 & $65-69$ & $\mathrm{~F}$ & CNS & -2 & 8.0 & 5 & 1.3 & 35.8 & & 1.0 & 3.3 & 842 & $\dagger$ \\
\hline $\mathrm{v}$ & 142 & $65-69$ & $\mathrm{~F}$ & Gastrointestinal & 6 & 23.0 & 321 & 1.2 & 33.7 & & 0.4 & 2.9 & 675 & \\
\hline $\mathrm{v}$ & 148 & $65-69$ & M & CNS (retinal with symptoms) & 13 & 0.8 & 105 & 1.1 & 36.8 & 2350 & 0.5 & 3.8 & 342 & \\
\hline $\mathrm{v}$ & 160 & $70-74$ & $\mathrm{~F}$ & CNS & 29 & 6.2 & 66 & 1.2 & 49.5 & 3830 & 1.2 & 3.6 & 1359 & \\
\hline
\end{tabular}




\begin{tabular}{|c|c|c|c|c|c|c|c|}
\hline Risk factor & & SHR & $95 \% \mathrm{Cl}$ & $P$ value & SHR & $95 \% \mathrm{Cl}$ & $P$ value \\
\hline \multirow[t]{2}{*}{ PT-INR } & $(>1.3-1.5$ vs. $\leq 1.3)$ & 8.49 & $2.80-25.79$ & $<.001$ & 7.72 & $2.53-23.56$ & $<.001$ \\
\hline & $(>1.5$ vs. $\leq 1.3)$ & 27.78 & $8.97-86.06$ & $<.001$ & 22.46 & $6.92-72.91$ & $<.001$ \\
\hline LDH & ( $\geq 2$ vs. $<2$ xULN) & 6.13 & $2.24-16.78$ & $<.001$ & - & & \\
\hline Platelets & ( $\leq 40$ vs. $>40 \times 109 / L)$ & 4.78 & $1.75-13.08$ & .002 & 3.63 & $1.31-10.05$ & .010 \\
\hline Albumin & (<3 vs. $\geq 3 \mathrm{~g} / \mathrm{dL}$ ) & 4.36 & $1.73-10.95$ & .002 & - & & \\
\hline PTT & ( $\geq 35$ vs. $<35 \mathrm{sec}$ ) & 4.58 & $1.64-12.80$ & .004 & - & & \\
\hline Bilirubin & (>1.2 vs. $\leq 1.2 \mathrm{mg} / \mathrm{dL})$ & 1.97 & $1.07-3.64$ & .030 & - & & \\
\hline NRAS & (yes vs. no) & 2.59 & $1.04-6.47$ & .042 & - & & \\
\hline WBC & $(\geq 25$ vs. $<25 \times 109 / L)$ & 2.49 & $1.02-6.09$ & .045 & - & & \\
\hline Age & ( $\geq 60$ vs. $<60$ years) & 0.43 & $0.17-1.06$ & .068 & - & & \\
\hline TET2 & (yes vs. no) & 2.37 & $0.92-6.08$ & .074 & - & & \\
\hline
\end{tabular}




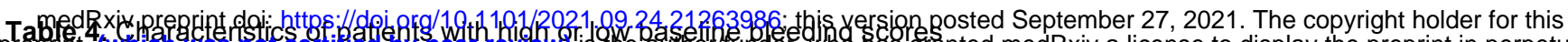
(he preprint in perpetuity.

\begin{tabular}{|c|c|c|c|c|c|c|c|c|c|c|}
\hline \multirow{3}{*}{ Age, years; median (range) } & \multicolumn{9}{|c|}{ It is malevalopment Graerta CC-BY-NC-ND 4.0 International lidealigation cohort } & \multirow{3}{*}{$\begin{array}{l}\boldsymbol{P} \text { value } \\
.202\end{array}$} \\
\hline & \multicolumn{2}{|c|}{$\begin{array}{c}\text { Low } \\
(n=297)\end{array}$} & \multicolumn{2}{|c|}{$\begin{array}{c}\text { High } \\
(\mathrm{n}=42)\end{array}$} & \multirow{2}{*}{$\begin{array}{l}\boldsymbol{P} \text { value } \\
.196\end{array}$} & \multicolumn{2}{|c|}{$\begin{array}{c}\text { Low } \\
(n=119)\end{array}$} & \multicolumn{2}{|c|}{$\begin{array}{c}\text { High } \\
(n=24)\end{array}$} & \\
\hline & 62 & $(19-76)$ & 59 & $(23-74)$ & & 63 & $(20-85)$ & 67 & $(37-78)$ & \\
\hline Sex & & & & & .413 & & & & & .819 \\
\hline Male & 162 & $55 \%$ & 20 & $48 \%$ & & 74 & $62 \%$ & 14 & $58 \%$ & \\
\hline Female & 135 & $45 \%$ & 22 & $52 \%$ & & 45 & $38 \%$ & 10 & $42 \%$ & \\
\hline ELN2017 cytogenetic risk group & & & & & .735 & & & & & .999 \\
\hline Favorable & 34 & $12 \%$ & 6 & $14 \%$ & & 11 & $9 \%$ & 2 & $8 \%$ & \\
\hline Intermediate & 204 & $70 \%$ & 27 & $64 \%$ & & 65 & $56 \%$ & 14 & $58 \%$ & \\
\hline Adverse & 55 & $19 \%$ & 9 & $21 \%$ & & 40 & $34 \%$ & 8 & $33 \%$ & \\
\hline \multicolumn{11}{|l|}{ Somatic mutations, presence } \\
\hline NPM1 & 81 & $27 \%$ & 9 & $21 \%$ & .463 & 19 & $16 \%$ & 6 & $25 \%$ & .375 \\
\hline DNMT3A & 64 & $22 \%$ & 9 & $21 \%$ & .999 & 21 & $18 \%$ & 2 & $8 \%$ & .367 \\
\hline NRAS & 50 & $17 \%$ & 11 & $26 \%$ & .139 & 18 & $15 \%$ & 6 & $25 \%$ & .241 \\
\hline$R U N X 1$ & 49 & $16 \%$ & 3 & $7 \%$ & .167 & 26 & $22 \%$ & 4 & $17 \%$ & .784 \\
\hline TET2 & 45 & $15 \%$ & 8 & $19 \%$ & .500 & 14 & $12 \%$ & 6 & $25 \%$ & .107 \\
\hline$A S X L 1$ & 41 & $14 \%$ & 4 & $10 \%$ & .627 & 22 & $18 \%$ & 3 & $13 \%$ & .768 \\
\hline FLT3-ITD & 44 & $15 \%$ & 7 & $17 \%$ & .817 & 16 & $13 \%$ & 4 & $17 \%$ & .747 \\
\hline$I D H 2$ & 31 & $10 \%$ & 7 & $17 \%$ & .291 & 21 & $18 \%$ & 1 & $4 \%$ & .125 \\
\hline SRSF2 & 32 & $11 \%$ & 5 & $12 \%$ & .793 & 22 & $18 \%$ & 1 & $4 \%$ & .125 \\
\hline$I D H 1$ & 37 & $12 \%$ & 3 & $7 \%$ & .445 & 12 & $10 \%$ & 1 & $4 \%$ & .696 \\
\hline TP53 & 18 & $6 \%$ & 5 & $12 \%$ & .183 & 24 & $20 \%$ & 2 & $8 \%$ & .248 \\
\hline FLT3-TKD & 29 & $10 \%$ & 3 & $7 \%$ & .781 & 13 & $11 \%$ & 4 & $17 \%$ & .488 \\
\hline \multicolumn{11}{|l|}{ Complete blood count } \\
\hline Hemoglobin, g/dL & 8.7 & $(8.1-9.4)$ & 8.3 & $(7.6-8.5)$ & $<.001$ & 8.7 & $(7.8-9.9)$ & 8.7 & $(8.2-10.1)$ & .713 \\
\hline Platelets, x109/L & 56 & $(32-98)$ & 29 & $(20-35)$ & $<.001$ & 65 & $(45-123)$ & 36 & $(26-55)$ & $<.001$ \\
\hline WBC, x109/L & 5.8 & $(2.3-19.0)$ & 18.3 & $(6.4-47.5)$ & $<.001$ & 6.6 & $(2.1-31.0)$ & 40.4 & $(15.8-73.0)$ & $<.001$ \\
\hline \multicolumn{11}{|l|}{ Coagulation } \\
\hline PT-INR & 1.2 & $(1.1-1.3)$ & 1.5 & $(1.4-1.6)$ & $<.001$ & 1.2 & $(1.1-1.3)$ & 1.6 & $(1.5-1.8)$ & $<.001$ \\
\hline PTT, sec & 32.4 & $(29.7-36.5)$ & 41.6 & $(34.9-48.4)$ & $<.001$ & 30.7 & $(27.8-34.1)$ & 34.3 & $(30.5-43.4)$ & .005 \\
\hline Fibrinogen, mg/dL & 374 & $(304-465)$ & 370 & $(257-460)$ & .429 & 430 & $(330-562)$ & 356 & $(146-547)$ & .031 \\
\hline D-dimer, ng/mL & 1526 & $(852->4000)$ & $>4000$ & $(2471->4000)$ & .010 & 1390 & $(569-3360)$ & 6618 & $(1670->20000)$ & .004 \\
\hline \multicolumn{11}{|l|}{ Chemistry } \\
\hline Creatinine, mg/dL & 0.81 & $(0.66-0.97)$ & 0.81 & $(0.69-1.00)$ & .656 & 0.90 & $(0.76-1.10)$ & 1.13 & $(0.96-1.49)$ & .001 \\
\hline Albumin, $\mathrm{g} / \mathrm{dL}$ & 3.6 & $(3.3-3.9)$ & 3.0 & $(2.6-3.5)$ & $<.001$ & 3.5 & $(3.1-4.0)$ & 3.2 & $(2.8-3.5)$ & .012 \\
\hline Bilirubin, mg/dL & 0.4 & $(0.3-0.7)$ & 0.6 & $(0.4-0.9)$ & .002 & 0.6 & $(0.4-1.0)$ & 0.6 & $(0.5-1.2)$ & .763 \\
\hline $\mathrm{LDH}, \mathrm{U} / \mathrm{L}$ & 312 & $(204-377)$ & 752 & $(457-1679)$ & $<.001$ & 833 & $(575-1359)$ & 2130 & $(1296-3603)$ & $<.001$ \\
\hline Thrombosis & & & & & .002 & & & & & .052 \\
\hline None & 264 & $89 \%$ & 30 & $71 \%$ & & 110 & $92 \%$ & 19 & $79 \%$ & \\
\hline Catheter associated & 23 & $8 \%$ & 6 & $14 \%$ & & 6 & $5 \%$ & 2 & $8 \%$ & \\
\hline Non-catheter associated & 10 & $3 \%$ & 6 & $14 \%$ & & 3 & $3 \%$ & 3 & $13 \%$ & \\
\hline
\end{tabular}

Abbreviations: ELN, European LeukemiaNET; IQR, interquartile range; LDH, lactate dehydrogenase; PT-INR, protrombin time international normalized ratio; PTT, partial thromboplastin time; WBC, white blood cells. 